\title{
Comparative study of the toxicity of hydroethanolic extracts of the root and stem barks of Cassia sieberiana D.C. on Wistar rats
}

\author{
Kodjo Selom Evenamede${ }^{1}$, Kafui Kpegba ${ }^{1}$, Kokou Idoh $^{2}$, Amegnona Agbonon ${ }^{2 *}$, Oudjaniyobi Simalou ${ }^{1}$, \\ Pakoupati Boyode', Oyegunle Emmanuel Oke ${ }^{3}$, Messanvi Gbeassor ${ }^{2}$ \\ ${ }^{1}$ Laboratory of Organic Chemistry and Natural Substances (Lab COSNat), Faculty of Sciences, University of Lomé, 01 BP 1515 Lomé 01, Lomé, Togo, \\ ${ }^{2}$ Department of Physiology, Laboratory of Physiology, Pharmacology, and Toxicology, Faculty of Sciences, University of Lomé, 01 BP 1515 Lomé 01 , Lomé, \\ Togo, ${ }^{3}$ Department of Animal Physiology, Federal University of Agriculture, Abeokuta, Nigeria
}

\begin{tabular}{l}
\hline ARTICLE INFO \\
\hline Article history: \\
Received on: September 12, 2018 \\
Accepted on: November 29, 2018 \\
Available online: April 05, 2019 \\
\hline Key words: \\
Cassia sieberiana, \\
Lethal dose, \\
Rat, \\
Toxicity
\end{tabular}

\begin{abstract}
This study was aimed to evaluate and to compare the acute and subchronic toxicities of the hydroethanolic extracts of the root (HECRB) and stem bark (HECSB) of Cassia sieberiana in rats. In acute toxicity study, animals were divided into 2 groups $(n=3)$. Rats received the single dose of $5000 \mathrm{mg} / \mathrm{kg}$ of HECRB and HECSB extracts of $C$. sieberiana orally. For the subchronic toxicity, 4 groups $(n=6)$ were given daily 500 and $1000 \mathrm{mg} / \mathrm{kg}$ of extracts for 28 days. Animal behaviors were observed after each treatment. Results showed that HECRB and HECSB were not toxic at $5000 \mathrm{mg} / \mathrm{kg}$. The $\mathrm{LD}_{50}$ was $>5000 \mathrm{mg} / \mathrm{kg}$ for both extracts. After repeated doses of 500 and $1000 \mathrm{mg} / \mathrm{kg}$, both extracts did not significantly affect the relative organs weight of treated rats. HECSB did not affect biochemical and hematological parameters. However, HECRB significantly increased parameters such as red and white blood cells, hemoglobin, volume globulaire moyen, teneur corpusculaire moyenne en hemoglobine, and triglycerides. This study showed that HECRB and HECSB are not toxic. It contributes to a better knowledge of the toxicity of $C$. sieberiana used for the treatment of several diseases in Togo.
\end{abstract}

\section{INTRODUCTION}

For centuries and even millennia, our ancestors used plants to relieve their pain, heal their ailments and wounds [1]. This tradition was handed down from one generation to the other. This is the reason why African populations continue to use plants that are used empirically as antimalarial, aphrodisiac, and antianemic and without worrying about their toxicity [2]. Thus, traditional medicine can be considered an integral part of primary health care. However, lack of standardization is an important concern for the use of natural medicine from medicinal plants [3]. On the other hand, although herbal health care is considered safe, some are known to be toxic in high dosages and others may have a potential negative effect after prolonged use. Several studies on traditional herbal treatments have reported toxicity or interaction problems that may cause treatment failures or accidents [4]. It, therefore, becomes important to assess the toxicity of medicinal plants used extensively in the traditional pharmacopeia [5].

Cassia sieberiana DC. (Caesalpiniaceae, synonym: Cassia kotschyana Oliv) is a widespread tropical plant in West Africa, Senegal, Benin, Mali, Burkina Faso, and Togo. It is widely used in traditional medicine in the treatment of several pathologies such as malaria, female infertility,

*Corresponding Author Amegnona Agbonon,

Department of Physiology, University of Lomé, Department of Physiology,

Laboratory of Physiology, Pharmacology, and Toxicology, Faculty of

Sciences, P.O. Box: 1515 Lomé, Togo.

Phone: (+228)-22-36-75-82.E-mail:evselom@yahoo.f hemorrhoids, abdominal pain, sexual impotence in men, and leprosy [6-9]. In Senegal, The Gambia, Guinea and Nigeria, C. sieberiana is used as an active arrow poison for hunting and fishing [10].

In Togo, the different organs of the plant are sold in local markets and are used as antimalarials. However, despite the widespread use of this plant in the treatment of several diseases throughout Africa, especially in Togo, there is a paucity of experimental data on its toxicity, although some authors have already pointed out that the plant is used as a poison for hunting and fishing. This study aimed at evaluating the 28-day acute and subchronic toxicity of the hydroethanolic extracts of the root and bark of $C$. sieberiana stem in Wistar strain rats.

\section{MATERIALS AND MÉTHODES}

\subsection{Plant Material}

The plant (C. sieberiana) were collected in November 2016 in the region of Danyi, $150 \mathrm{~km}$ north-west of Lomé (Togo). Botanical authentication was confirmed at the Department of Botany, University of Lomé, where a specimen of $C$. sieberiana coupon was deposited in the Togolese flora herbarium (Togo 15445).

\subsection{Phytochemicals Screening}

The major chemical groups of the plant (root and stem bark powder) were determined by a study based on solubility tests, staining and precipitation reactions as well as ultraviolet light examinations [11,12]. 


\subsection{Preparation of the Crude Extracts}

The powder of the stem bark and the root bark of C. sieberiana $(100 \mathrm{~g})$ was poured at room temperature into a liter of the ethanol/water mixture $(70 / 30 ; \mathrm{v} / \mathrm{v})$ for $72 \mathrm{~h}$, stirring at regular intervals. The resulting mixture was filtered, and the filtrate was concentrated by evaporation of the ethanol-water mixture at $40^{\circ} \mathrm{C}$ under reduced pressure using a rotary evaporator (BUCHI, Switzerland). The yield of the extract was calculated in relation to the initial weight of the dry plant powder.

\subsection{Animals}

Healthy Wistar rats of both sexes weighing between 93 and $130 \mathrm{~g}$ used in the present study were provided by animals facilities of the Laboratory of Physiology, Pharmacology, and Toxicology of the Faculty of Sciences, University of Lomé. Animals were housed and divided by sex in cages (six rats per cage) at ambient temperature and humidity with a $12 \mathrm{~h}$ day-light cycle, with free access to food and water ad libitum. Experimental protocols were based on the World Health Organization Guidelines (Organization for Economic Cooperation and Development [OECD]) [13] for care and use of laboratory animals, and the use of the animals was approved by the Ethics Committee of the University of Lomé, a branch of the National Ethics Committee for control and supervision of experiments on animals $\left(\mathrm{N}^{\circ} \mathrm{SBM} / \mathrm{UL} / 15\right.$ / NS0009).

\subsection{Acute Toxicity}

The study of the acute toxicity of the extracts of the bark and root of C. sieberiana was carried out according to the guideline 423 of the OECD [13]. In total, nine female rats assigned to three groups of three were used. A first (control group) received distilled water while the other two groups received an oral dose of a single dose of $5000 \mathrm{mg} / \mathrm{kg}$ body weight $(\mathrm{BW})$ of extract. The animals fasted for $12 \mathrm{~h}$ before administration of the extracts. After gavage, the rats were retained for an additional 3-4 h. The animals were observed individually at least once every $30 \mathrm{~min}$ after administration, periodically during the first $24 \mathrm{~h}$ (with special attention during the first $4 \mathrm{~h}$ ) and daily for a period of 14 days. Observations on behavior included mobility, agitation, respiration, asthenia, changes (hairs, eyes, and mucous membranes), tremor, convulsion, feces appearance, lethargy, sleep, and coma. Animals that died during the observation period were subjected to autopsy. On the $15^{\text {th }}$ day, the surviving animals were all sacrificed, and vital organs including the liver, kidneys, lungs, and heart were removed and subjected to macroscopic observation.

\subsection{Subchronic Toxicity}

To study the oral subchronic toxicity of $C$. sieberiana stem bark and root bark extracts, the OECD protocol [14], taken up by Diallo et al. [15] and Bakoma et al. [16], was used. Wistar rats of initial BW between 93 and $135 \mathrm{~g}$ were allocated into three groups of 6 ( 3 males and 3 females). Two groups received doses of 500 and $1000 \mathrm{mg} / \mathrm{kg} \mathrm{BW}$ daily for 28 days of extracts from the root and stem bark of $C$. sieberiana, representing the two active doses of the trials pharmacological studies carried out previously in our laboratory. The $3^{\text {rd }}$ group (control group) was treated with distilled water over the same period. The behavior of the rats was observed each day, and their weight measured every 2 days. The blood of each animal was taken on the $29^{\text {th }}$ day by retro-orbital puncture. Blood was collected in two types of tubes: For hematological tests, blood was taken from tubes containing ethylenediaminetetraacetic acid (EDTA) as an anticoagulant, while for biochemical tests; blood was taken from dry tubes. All animals were then sacrificed, and the organs such as the liver, spleen, kidneys, heart, and lung were removed, weighed and then macroscopically examined for possible lesions or signs of toxicity. The relative weights of the organs were determined according to the following formula:

$\mathrm{RW}=($ Organ weight $/ \mathrm{BW}$ per rat $) \times 100$.

\subsection{Hematological Parameters Analysis}

Blood samples taken from tubes containing an anticoagulant (EDTA) were immediately used to determine the levels of white blood cells, red blood cells, hemoglobin, platelets (PLT) and hematocrit, mean globular volume (MGV), mean corpuscular hemoglobin content $(\mathrm{MCH})$, and mean corpuscular hemoglobin concentration (MCHC). These hematological parameters were determined using an automatic hematology analyzer (Mindray BC-2800, China).

\subsection{Biochemical Parameters Analysis}

The blood samples in the tubes without anticoagulant were centrifuged at $3000 \mathrm{rpm}$ for $10 \mathrm{~min}$. The serum collected was stored at $-20^{\circ} \mathrm{C}$. and used to analyze for enzymes such as transaminases (alanine aminotransferase [ALT], aspartate aminotransferase from aspartate $[\mathrm{AST}]$, and alkaline phosphatase [ALP]), total bilirubin, total cholesterol, and triglycerides as biochemical indicators of damage and/or liver dysfunction. Kidney dysfunction was assessed at the blood level by the dosage of creatinine and urea. The glucose level was measured to evaluate the pancreatic function. Standard diagnostic kits from Human GmbH. D-65205 (Wiesbaden, Germany) were used for the spectrophotometric determination of the biochemical parameters.

\subsection{Statistical Analysis}

All statistical analyzes were performed by GraphPad Prism software 5.00 (Software Inc., USA). The results were expressed as mean \pm standard error of mean. The statistical analysis was performed by a one-way analysis of ANOVA followed by the Tukey test to evaluate significant differences between groups. The values were considered to be significantly different when $P<0.05$.

\section{RESULTS}

\subsection{Phytochemicals Screening}

The phytochemical study carried out showed that the bark of the stem and the bark of the roots of C. sieberiana contained flavonoids, anthraquinones, tannins, reducing compounds, mucilages, and coumarins. However, the absence of free quinones and alkaloids in both parts of the plant was observed. Anthocyanins were present in the stem bark, but they were absent in the root bark.

\subsection{Acute Oral Toxicity Study}

The $5000 \mathrm{mg} / \mathrm{kg}$ (bark and root) dose did not cause mortality or clinical signs of acute toxicity in rats observed for a short period of $48 \mathrm{~h}$ and a long period (14 days). No abnormalities were observed in the organs during necropsy.

\subsection{8-Day Subchronic Oral Toxicity Study}

\subsubsection{General behavior and mortality}

Oral administration of $C$. sieberiana extracts (stem and root bark) for 28 consecutive days did not induce any clear symptoms of toxicity in the rat, including the highest dose tested of $1000 \mathrm{mg} / \mathrm{kg} \mathrm{BW}$ per day. No mortality was recorded during the 28 days of administration 
of the extract. No differences in overall behavior, feed, and water consumption were observed among groups of rats.

\subsubsection{Effect of the hydroethanolic extracts $C$. sieberiana stem bark (HECSB) on the BW of rats}

At doses of $500 \mathrm{mg} / \mathrm{kg}$ and $1000 \mathrm{mg} / \mathrm{kg}$, HECSB had no significant effect $(P<0.01)$ on the BW of the treated rats [Figure 1]. In the $1^{\text {st }}$ week [Figure 1], a remarkable increase in the weight of the rats was observed irrespective of the dose of stem bark extract administered $(500 \mathrm{mg} / \mathrm{kg}$ and $1000 \mathrm{mg} / \mathrm{kg})$. The same was observed in the rats which received only distilled water (controls). On the other hand, in the $2^{\text {nd }}$ week, the weight of the rats remained constant while that of the controls increased. From the $14^{\text {th }}$ to $28^{\text {th }}$ day, both the doses of $500 \mathrm{mg} / \mathrm{kg} / \mathrm{BW}$ and $1000 \mathrm{mg} / \mathrm{kg} / \mathrm{BW}$ slowed down the weight of the treated rats as compared to the control animals. At the end of the gavage, a difference in weight between control rats and those receiving extracts from the stem bark was recorded, but this difference was not significant $(P<0.05)$.

\subsubsection{Effect of hydroethanolic extracts $C$. sieberiana root bark (HECRB) on $B W$ of rats}

In the first 2 weeks [Figure 2], rats given $1000 \mathrm{mg} / \mathrm{kg} / \mathrm{BW}$ of root bark extract (HECRB) had a virtually constant weight. In contrast, rats which were given a dose of $500 \mathrm{mg} / \mathrm{kg}$ of extract showed a slight increase in weight. The weight of the treated rats increased significantly in the ASAT 2 weeks irrespective of the dose administered.

Compared to controls, root bark extracts reduced the BW of treated animals, but this reduction was not significant $(P<0.05)$. This reduction was much more observable in rats given the dose of $1000 \mathrm{mg} / \mathrm{kg} / \mathrm{BW}$.

\subsubsection{Effects of an hydroethanolic extracts of $C$. sieberiana stem bark (HECSB) on the relative organ weight in rats}

There was no significant effect of the extracts on the relative weight of the liver, heart, lungs, spleen, and kidneys of the treatment compared to the control rats [Table 2]. No gross disease related to treatment was observed.

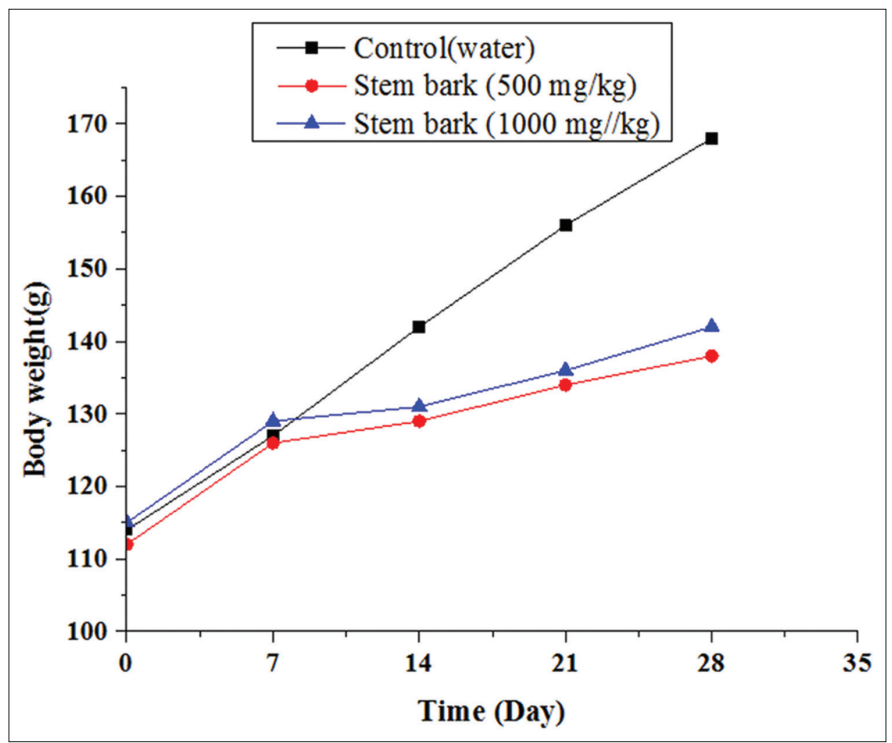

Figure 1: Effects of Cassia sieberiana stem bark on the body weight evolution of rats
3.3.5. Effects of hydroethanolic extracts $C$. sieberiana root bark (HECRB) on the relative weight of organs in rats

At the end of the 4 weeks of treatment with HECRB, the relative weights of the organs taken did not vary significantly $(P>0.05)$ compared to controls [Table 3]. This was not the case for the lungs of treated rats. Regardless of the dose administered, lung weight of the treated rats increased significantly $(P<0.05)$.

\subsubsection{Effect of hydroethanolic extracts $C$. sieberiana stem bark (HECSB) on biochemical parameters}

The study revealed that oral administration of the extract of $C$. sieberiana peel for 28 days did not show significant influence on ALP and AST except a non-significant decrease. On the other hand, a significant decrease in ALT was observed.

The levels of total and direct bilirubins were decreased non-significantly $(P>0.05)$ in rats treated with the stem bark of $C$. sieberiana [Table 4].

\subsubsection{Effect of hydroethanolic extracts $C$. sieberiana root bark (HECRB) on biochemical parameters}

The results of Table 4 show the effects of $C$. sieberiana extract $(500 \mathrm{mg} / \mathrm{kg} / \mathrm{BW}$ and $1000 \mathrm{mg} / \mathrm{kg} / \mathrm{BW})$ on biochemical parameters in rats (male and female). Results showed that oral administration of C. sieberiana root bark extract for 28 days had no effect on biochemical parameters in treated rats except serum triglycerides which increased significantly $(P<0.05)$ as compared to control rats [Table 5].

\subsubsection{Effect of hydroethanolic extracts $C$. sieberiana stem bark (HECSB) on hematological parameters in rats}

Hematological analysis showed no significant changes in hematological parameters. However, a non-significant decrease $(P>0.05)$ in the numbers of white blood cells, PLT, hemoglobin, $\mathrm{MCH}$, and $\mathrm{MCHC}$ of treated groups versus control group was recorded [Table 6]. On the other hand, the number of red blood cells increased slightly, but this increase was not significant $(P>0.05)$.

\subsubsection{Effect of hydroethanolic extracts $C$. sieberiana root bark (HECRB) on hematological parameters in rats}

The results in Table 6 show that red blood cells, hemoglobin, and mean corpuscular volume $(\mathrm{MCH})$ levels increased significantly $(P<0.05)$ at the end of the experiment at any dose administered to rats. White blood cells and hematocrit levels also increased for both doses except that this increase was not significant $(P>0.05)$ [Table 7].

\section{DISCUSSION}

The phytochemical analysis carried out in the present study showed that the barks of the stem and roots of $C$. sieberiana contained large chemical groups, namely flavonoids, anthraquinones, tannins, reducing compounds, mucilages, and coumarins. However, there was no free quinones and alkaloids in both parts of the plant. Anthocyanins were present in the bark and were absent in the roots [Table 1]. Studies of Asase et al. [17] have also shown that the bark of the same plant from Ghana also contains flavonoids. The alkaloids are strongly present in the species of Ghana [17]. However, they were absent in the C. sieberiana of Togo used in this study. The richness of the C. sieberiana species in these large groups of active chemical compounds could then explain the traditional use of this plant to treat many diseases such as constipation, hypertension and malaria [7], and sterility [9]. Indeed, other researchers have also shown that the different types of chemical compounds found in the bark of this plant 


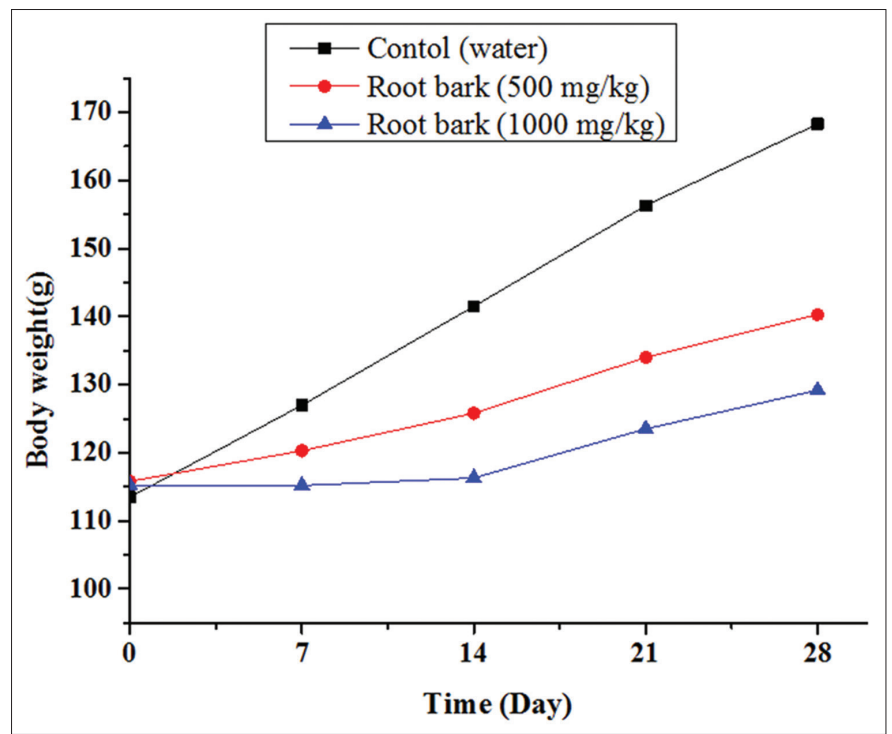

Figure 2: Effects of Cassia sieberiana root bark extract on the body weight evolution of rats

Table 1: Results of phytochemical screening of the two parts of the plant

\begin{tabular}{lcc} 
Compounds & Stem bark & Root bark \\
Alkaloids & - & - \\
Flavonoids & + & + \\
Saponosides & + & + \\
Cardiotonic heterosides & + & + \\
Anthraquinones & + & + \\
Tanins & + & + \\
Anthocyanins & + & - \\
Free quinones & - & - \\
Sugar reducer & + & + \\
Mucilage & + & + \\
Coumarins & + & + \\
\hline
\end{tabular}

- : Negative reaction, + : Positive reaction

Table 2: Effect of HECSB on mean relative organ weight (\%)

\begin{tabular}{lccc} 
Organs & Control & \multicolumn{2}{c}{ Extract doses $(\mathbf{m g} / \mathbf{k g} / \mathbf{d a y})$} \\
\cline { 3 - 4 } & & $\mathbf{5 0 0} \mathbf{~} \mathbf{g g} / \mathbf{k g} / \mathbf{B W}$ & $\mathbf{1 0 0 0} \mathbf{~ m g} / \mathbf{k g} / \mathbf{B W}$ \\
Heart & $0.312 \pm 0.008$ & $0.338 \pm 0.011$ & $0.357 \pm 0.024$ \\
Liver & $2.953 \pm 0.189$ & $2.868 \pm 0.073$ & $2.641 \pm 0.152$ \\
Spleen & $0.245 \pm 0.022$ & $0.216 \pm 0.022$ & $0.221 \pm 0.025$ \\
Waist & $0.570 \pm 0.015$ & $0.622 \pm 0.029$ & $0.585 \pm 0.029$ \\
Lungs & $0.424 \pm 0.010$ & $0.545 \pm 0.021 *$ & $0.605 \pm 0.042 * *$ \\
\hline
\end{tabular}

Values are expressed as mean \pm ESM $(n=6)$, No significant difference between the control group and the treated groups $(P>0.05$ ), (ANOVA one-way followed by Tukey's multiple comparison test). HECSB: Hydroethanolic extract of Cassia sieberiana stem bark

have proven therapeutic effects [18]. The study of the acute toxicity of hydroethanolic extracts of C. sieberiana's stem bark (HECSB) and root (HECRB) revealed no particular signs of toxicity during the 14 days of observations. There was neither death of rats nor significant changes in behavior during this period. The macroscopic examination of the organs at the autopsy on the $15^{\text {th }}$ day revealed no abnormalities of these organs. These results indicate that the median value of acute toxicity or the $\mathrm{LD}_{50}$ of each extract was $>5000 \mathrm{mg} / \mathrm{kg}$. Previous studies have shown that any product with an $\mathrm{LD}_{50}>5000 \mathrm{mg} / \mathrm{kg}$ orally could be considered practically non-toxic [19]. The $\mathrm{LD}_{50}$ is $>5000 \mathrm{mg} / \mathrm{kg}$ low toxicity, which presages the safe use of $C$. sieberiana macerate.

The results of subchronic toxicity showed that daily administration of HECSB and HECRB (500 mg/kg/BW and $1000 \mathrm{mg} / \mathrm{kg} / \mathrm{BW})$ for 28 days did not cause death nor clinical signs of toxicity in animals. The significant reduction in BW and the significant change in the relative weights of the internal organs are significant indices of toxicity after exposure to toxic substances [20]. In this study, there was an insignificant reduction in weight gain at the end of the $4^{\text {th }}$ week [Figures 1 and 2]. This result could be attributed to the suppression of the appetite of the animals by the two extracts thus leading to reduced food consumption [21]. This result could also be related to the presence of tannins in the two extracts. Indeed, the tannins can, by interacting with the food consumed, causing a reduction in the weight of the treated rats. This is due to the fact that tannins are phenolic compounds having the power to form indigestible complexes with nutrients from foods, or with the body's proteins such as digestive enzymes. It is the formed complex that induces a decrease in nutritional efficiency [22].

Hematologic indices in animals are important for toxicity risk assessment. Changes in hematological parameters in blood content constitute a predictive value for toxicity [20]. The results obtained in our study show that all hematological parameters are normal for the groups treated with the HECSB regardless of the dose administered. This was not the case for rats treated with $C$. sieberiana root bark hydroethanolic extract (HECRB). The results showed a significant increase in red blood cell levels correlated with a significant increase in hemoglobin, $\mathrm{MGV}$, and $\mathrm{MCH}$ for all doses administered. These indices suggest that the extract is not toxic for hematological parameters. An increase in white blood cells indicates a strengthening of the body's defense [23,24].

Hydroethanolic extract of stem bark (HECSB) from C. sieberiana at different doses had no effect on the biochemical parameters of the treated rats. ALT and AST are serum marker enzymes associated with health indices [25]. They are usually used to diagnose and assess health status or signs of toxicity, especially liver damage [25]. Moreover, the amount of enzyme released into the blood is directly proportional to the number of damaged cells and the time interval between the injury and the test [26]. Apart from the liver, AST is also found in the heart, skeletal muscles, lungs, and kidneys [27]. Moreover, an increase in the concentration of ALP in the serum is a sign of the obstruction of the bile duct [28]. In this study, HECSB caused a slight decrease in transaminase and ALP levels in treated rats compared with control rats at any dose $(500 \mathrm{mg} / \mathrm{kg}$ and $1000 \mathrm{mg} / \mathrm{kg})$. However, there were no statistically significant differences $(P>0.05)$. This decrease in the transaminase level observed shows that, on the one hand, the C. sieberiana HECSB did not have a hepatotoxic effect and, on the other hand, the extract had not caused toxic effects on the cardiac tissue. These results are confirmed by data on relative organ weights [Table 1]. Researchers have shown that the change in the relative weights of internal organs is a sensitive index of toxicity after exposure to toxic substances $[29,30]$. Thus, when rats are exposed to toxic substances, then the relative weight of the injured organs should either decrease or increase significantly. However, the results of this study showed that there was no significant effect on the relative weight of the liver, heart, lungs, spleen, and kidneys of the treated rats compared to the control rats. No gross disease related to treatment was observed. Thus, the 
Table 3: Effect of HECRB on mean relative organ weight (\%)

\begin{tabular}{lccc} 
Organs & Control & \multicolumn{2}{c}{ Extract doses $(\mathbf{m g} / \mathbf{k g} / \mathbf{d a y})$} \\
\cline { 3 - 4 } & & $\mathbf{5 0 0} \mathbf{~ m g} / \mathbf{k g} / \mathbf{B W}$ & $\mathbf{1 0 0 0} \mathbf{~ m g} / \mathbf{k g} / \mathbf{B W}$ \\
Heart & $0.319 \pm 0.004$ & $0.299 \pm 0.003$ & $0.304 \pm 0.010$ \\
Liver & $3.299 \pm 0.156$ & $3.296 \pm 0.093$ & $3.245 \pm 0.121$ \\
Spleen & $0.278 \pm 0.007$ & $0.254 \pm 0.013$ & $0.268 \pm 0.007$ \\
Waist & $0.592 \pm 0.008$ & $0.6433 \pm 0.012$ & $0.653 \pm 0.028$ \\
Lungs & $0.425 \pm 0.010$ & $0.460 \pm 0.013$ & $0.466 \pm 0.013$ \\
\hline
\end{tabular}

Values are expressed as mean $\pm \operatorname{ESM}(n=6)$, no significant difference between the control group and the treated groups $(P>0.05)$. HECRB: Hydroethanolic extract of C. sieberiana root bark

Table 4: Effect of HECSB on biochemical parameters

\begin{tabular}{lccc} 
Blood parameters & Control & \multicolumn{2}{c}{ Extract doses (mg/kg/day) } \\
\cline { 3 - 4 } & & $\mathbf{5 0 0} \mathbf{~ m g / k g / B W}$ & $\mathbf{1 0 0 0} \mathbf{~ m g} / \mathbf{k g} / \mathbf{B W}$ \\
Globules blancs $\left(10^{9} / \mathrm{L}\right)$ & $10.65 \pm 1.31$ & $7.775 \pm 0.1887$ & $8.05 \pm 0.4674$ \\
Globules rouges $\left(10^{12} / \mathrm{L}\right)$ & $7.925 \pm 0.3029$ & $8 \pm 0.067$ & $8.133 \pm 0.080$ \\
Hemoglobin (g/dL) & $14.7 \pm 0.282$ & $14.38 \pm 0.159$ & $14.5 \pm 0.077$ \\
Hematocrit: $(\%)$ & $46.08 \pm 0.6544$ & $46.63 \pm 0.4694$ & $46.48 \pm 0,6911$ \\
MGV (fL) & $57.2 \pm 1.125$ & $58 \pm 0.6062$ & $56.57 \pm 1.114$ \\
MCH (pg) & $18.15 \pm 0.1975$ & $17.95 \pm 0.2317$ & $17.82 \pm 0.2088$ \\
MCHC (g/dL) & $31.85 \pm 0.3871$ & $30.98 \pm 0.2358$ & $31.58 \pm 0.2892$ \\
PLT (10 $3 / \mu L)$ & $459.5 \pm 64.78$ & $410.8 \pm 18.04$ & $375.3 \pm 19.68$ \\
\hline
\end{tabular}

Values are expressed as mean $\pm \mathrm{ESM}, n=6,{ }^{*} P<0.05, * * P<0.01$ (ANOVA one-way followed by Tukey's multiple comparison test), MGV: Mean globular volume, $\mathrm{MCH}$ : Mean corpuscular hemoglobin content, MCHC: Mean corpuscular hemoglobin concentration, PLT: Platelets. HECSB: Hydroethanolic extract of C. sieberiana stem bark

Table 5: Effect of HECRB on biochemical parameters in rats

\begin{tabular}{|c|c|c|c|}
\hline \multirow{2}{*}{$\begin{array}{l}\text { Biochemical } \\
\text { parameters }\end{array}$} & \multirow[t]{2}{*}{ Control } & \multicolumn{2}{|c|}{ Extract doses (mg/kg/day) } \\
\hline & & $500 \mathrm{mg} / \mathrm{kg} / \mathrm{BW}$ & $1000 \mathrm{mg} / \mathrm{kg} / \mathrm{BW}$ \\
\hline Triglycerides (g/L) & $0.292 \pm 0.043$ & $0.2405 \pm 0.021$ & $0.347 \pm 0.065$ \\
\hline Glucose (g/dL) & $0.819 \pm 0.092$ & $0.612 \pm 0.042$ & $0.747 \pm 0.061$ \\
\hline Total proteine $(\mathrm{g} / \mathrm{L})$ & $47.967 \pm 7.070$ & $36.883 \pm 4.610$ & $34.650 \pm 1.870$ \\
\hline Creatinine $(\mathrm{mg} / \mathrm{L})$ & $0.292 \pm 0.048$ & $0.225 \pm 0.022$ & $0.240 \pm 0.012$ \\
\hline Total bilirubin & $0.265 \pm 0.099$ & $0.107 \pm 0.022$ & $0.112 \pm 0.020$ \\
\hline Direct bilirubin & $0.260 \pm 0.033$ & $0.75 \pm 0.023$ & $0.247 \pm 0.017$ \\
\hline $\operatorname{ALT}(\mathrm{U} / \mathrm{L})$ & $29.983 \pm 3.92$ & $33.083 \pm 6.21$ & $28.750 \pm 4.63$ \\
\hline $\operatorname{AST}(\mathrm{U} / \mathrm{L})$ & $77.900 \pm 17.33$ & $53.883 \pm 7.895$ & $51.800 \pm 5.208$ \\
\hline $\operatorname{ALP}(\mathrm{U} / \mathrm{L})$ & $83.333 \pm 11.3$ & $71.000 \pm 11.6$ & $67.500 \pm 6.59$ \\
\hline
\end{tabular}

Values are expressed as mean \pm ESM, $n=6, * P<0.05$ significant difference compared to controls (ANOVA one-way followed by Tukey multiple comparison test), AST: Aspartate aminotransferase, ALT: Alanine aminotransferase, ALP: Alkaline phosphatase. HECRB: Hydroethanolic extract of $C$. sieberiana root bark

extract of the bark of the stem of $C$. sieberiana had a positive effect on the functioning of the vital organs such as the kidneys and the liver. In addition to decreased transaminases, HECSB also decreased serum glucose, total bilirubin, and total proteins significantly $(P>0.05)$. As a result, the bark could be used to treat patients suffering from hyperglycemia. However, the results of the biochemical parameters obtained with HECRB revealed a non-significant decrease in the total protein concentration. Similarly, HECRB acted on triglycerides by significantly increasing $(P<0.05)$ their serum level. HECRB acted on the metabolism of fatty acids and triglycerides. Concerning total
Table 6: Effect of HECSB on the hematological parameters

\begin{tabular}{lccc} 
Biochemical & Control & \multicolumn{2}{c}{ Extract doses $\mathbf{( m g / k g} / \mathbf{d a y})$} \\
\cline { 3 - 4 } parameters & & $\mathbf{5 0 0} \mathbf{~ m g} / \mathbf{k g} / \mathbf{B W}$ & $\mathbf{1 0 0 0} \mathbf{~ m g} / \mathbf{k g} / \mathbf{B W}$ \\
Triglycerides (g/L) & $0.377 \pm 0.015$ & $0.410 \pm 0.020^{*}$ & $0.528 \pm 0.047 * *$ \\
Glucose (g/dL) & $0.925 \pm 0.061$ & $0.88 \pm 0.060$ & $0.730 \pm 0.160$ \\
Total proteins (g/L) & $62.93 \pm 1.873$ & $59.75 \pm 2.05$ & $56.82 \pm 2.674$ \\
Creatinine (mg/L) & $0.387 \pm 0.026$ & $0.37 \pm 0.014$ & $0.361 \pm 0.025$ \\
Total bilirubin & $0.377 \pm 0.082$ & $0.2417 \pm 0.047$ & $0.610 \pm 0.150$ \\
Direct bilirubin & $0.277 \pm 0.044$ & $0.256 \pm 0.031$ & $0.31 \pm 0.077$ \\
ALT (U/L) & $36.720 \pm 1.981$ & $40.25 \pm 2.260$ & $43.800 \pm 8.967$ \\
AST (U/L) & $114.900 \pm 6.510$ & $111 \pm 11.310$ & $118 \pm 19.740$ \\
PAL (U/L) & $85.670 \pm 10.500$ & $84.5 \pm 9.629$ & $81.5 \pm 9.580$ \\
\hline
\end{tabular}

Values are expressed as mean $\pm \mathrm{ESM}, n=6 ;{ }^{*} P<0.05 ; * * P<0.01$ significant difference compared to controls (ANOVA one-way followed by Tukey multiple comparison test), AST: Aspartate Aminotransferase, ALT: Alanine aminotransferase, ALP: Alkaline phosphatase. HECSB: Hydroethanolic extract of C. sieberiana stem bark

Table 7: Effect of HECRB extract on hematological parameters

\begin{tabular}{|c|c|c|c|}
\hline \multirow[t]{2}{*}{ Blood parameters } & \multirow[t]{2}{*}{ Control } & \multicolumn{2}{|c|}{ Extract doses (mg/kg/day) } \\
\hline & & $500 \mathrm{mg} / \mathrm{kg} / \mathrm{BW}$ & $1000 \mathrm{mg} / \mathrm{kg} / \mathrm{BW}$ \\
\hline White blood cells $\left(10^{9} / \mathrm{L}\right)$ & $9.547 \pm 0.871$ & $14.65 \pm 1.52 * *$ & $15.59 \pm 2.595 * *$ \\
\hline Red blood cells $\left(10^{12} / \mathrm{L}\right)$ & $8.662 \pm 0.368$ & $9.612 \pm 0.1393 *$ & $10.03 \pm 0.073^{* *}$ \\
\hline Hemoglobin (g/dL) & $15.33 \pm 0.384$ & $16.32 \pm 0.218$ & $16.63 \pm 0.204^{*}$ \\
\hline Hematocrit: (\%) & $48.03 \pm 1.37$ & $50.49 \pm 1.114$ & $51.68 \pm 0.820$ \\
\hline MGV (fL) & $55.68 \pm 1.085$ & $52.5 \pm 0.445^{*}$ & $51.53 \pm 0.557 * *$ \\
\hline $\mathrm{MCH}(\mathrm{pg})$ & $17.71 \pm 0.289$ & $16.98 \pm 0.072 *$ & $16.57 \pm 0.1126^{* *}$ \\
\hline $\mathrm{MCHC}(\mathrm{g} / \mathrm{dL})$ & $31.92 \pm 0.4629$ & $32.33 \pm 0.307$ & $32.17 \pm 0.143$ \\
\hline $\operatorname{PLT}\left(10^{3} / \mu \mathrm{L}\right)$ & $723.1 \pm 70.84$ & $886.3 \pm 89.8$ & $775.5 \pm 64.8$ \\
\hline
\end{tabular}

Values are expressed as mean $\pm \mathrm{ESM}, n=6$; $* P<0.05, * * P<0.01$ (ANOVA one-way followed by Tukey's multiple comparison test), MGV: Mean globular volume, $\mathrm{MCH}$ : Mean corpuscular hemoglobin content, MCHC: Mean corpuscular hemoglobin concentration, PLT: Platelets. HECRB: Hydroethanolic extract of C. sieberiana root bark

bilirubin and direct bilirubin, the results obtained are disparate for both HECSB and HECRB. However, the differences from the control were not significant. All the results showed that the two extracts had no effect on the biochemical parameters of the treated rats.

\section{CONCLUSION}

The determination of the major chemical groups of the extracts was carried out to contribute to their valorization with the aim of better exploitation of the plant. All the toxicological results obtained favor a safety in the moderate use of maceration at the therapeutic dose for a short and long duration. Hydroethanolic root and stem barks extracts are not toxic at a single dose of $5000 \mathrm{mg} / \mathrm{kg} \mathrm{BW}$.

At different doses over a long period, the two extracts slowed down the increase in weight of the animals. The extracts did not induce any changes with respect to the biochemical parameters of the treated rats. This result reassured that the two extracts have no toxic effect on the liver, kidneys, and pancreas. The root promotes an increase in white blood cells, red blood cells, and hemoglobin levels. It could also be used against anemia.

This study has contributed to a better knowledge of the toxicity of C. sieberiana used for the treatment of several pathologies in Togo. 


\section{AUTHORS' CONTRIBUTION}

All authors participated in reading the paper and its drafting. All authors read and agreed to the final manuscript.

\section{REFERENCES}

1. Benkhnigue O, Zidane L, Fadli M, Elyacoubi H, Rochdi A, Douira A. Etude ethnobotanique des plantes médicinales dans la région de Mechraâ Bel Ksiri (Région du Gharb du Maroc). Acta Bot Barcinonensia 2011;53:191-216.

2. Sakande J, Ahiboh H, Edjelme A, Yapo AE. Etude de la tolerance biologique d'une plante a activité antiplasmodiale Momordica Charantia L (Cucurbitaceae). Mali Méd 2003;28:1-4.

3. Angell M, Kassierr JP. Alternative medicine - The risk of untested and unregulated remedies. N Engl J Med 1998;339:839-841.

4. Salhi S, Fadli M, Zidane L, Douira A. Etudes floristique et ethnobotanique des plantes médicinales de la ville de Kénitra (Maroc). Lazaroa 2010;31:133-46.

5. Zeggwagh AA, Lahlou Y, Bousliman Y. Enquete sur les aspects toxicologiques de la phytotherapie utilisee par un herboriste à Fes, Maroc. Pan Afr Med J 2013;14:1-6.

6. Kpegba K, Agbonon A, Petrovic AG, Amouzou E, Gbeassor M, Proni G, et al. Epiafzelechin from the root bark of Cassia sieberiana: Detection by DART mass spectrometry, spectroscopic characterization, and antioxidant properties. J Nat Prod 2011;74:455-9.

7. Asase A, Oteng-Yeboah AA, Odamtten GT, Simmonds MS. Ethnobotanical study of some ghanaian anti-malarial plants. J Ethnopharmacol 2005;99:273-9.

8. Idakwoji PA, Uzuazokaro MMA. Anti- radical and inhibitory effect of some common Nigerian medicinal plants on alpha glucosidase, aldose reductase and angiotensin converting enzyme: Potential protective mechanisms against diabetic complications. Int J Adv Res Biol Sci 2018;5:188-201.

9. Sy GY, Fall AD, Diatta W, Gueye M, Badji K, Bassène E, et al. Analgesic and anti-inflammatory activity of aqueous root extract of Cassia sieberiana D.C. (Caesalpiniaceae). Afr J Pharm Pharm 2009;3:651-3.

10. Neuwinger HD. Plants used for poison fishing in tropical africa. Toxicon 2004;44:417-30.

11. Khaldi A, Meddah B, Moussaou A, Benmehdi H, Gouri S. Screening phytochimique et effet antifongique de certains extraits de plantes sur le developpement in vitro des moisissures. Eur J Sci Res 2012;80:311-21

12. Sammama A, Azoungad A, El yahyaoui O, Kerrouri S, Bouabid B, Abdellahi LO, et al. Phytochemical study and compounds evaluation of antioxidant activity phenolic of the essential oil of the fruit: Citrus aurantium spp. Amara (Bitter orange). Eur J Biotechnol Biosci 2018;6:18-25

13. OECD. Guidelines for the Testing of Chemicals/Section 4. Paris, France: Health Effects Test No 423, Acute Oral Toxicity-acute Toxic Class Method; 2002.

14. OECD. Repeated dose oral toxicity test method. In: OECD Guidelines for Testing of Chemicals, $N^{\circ}$ 407. Paris, France; 2008.

15. Diallo A, Eklu-Gadegbeku K, Agbonon A, Aklikokou K, Creppy EE, Gbeassor M. Acute and sub-chronic (28 days) oral toxicity studies of hydroalcohol leaf extract of Ageratum conyzoides L (ASA Teraceae). Trop J Pharm Res 2010;9:463-7.

16. Bakoma B, Berké B, Eklu-Gadegbeku K, Agbonon A, Aklikokou K, Gbeassor M, et al. Acute and sub-chronic (28days) oral toxicity evaluation of hydroethanolic extract of Bridelia ferruginea benth root bark in male rodent animals. Food Chem Toxicol 2013;52:176-9.

17. Asase A, Kokubun T, Grayer RJ, Kite G, Simmonds MS, OtengYeboah AA, et al. Chemical constituents and antimicrobial activity of medicinal plants from Ghana: Cassia sieberiana, Haematostaphis barteri, Mitragyna inermis and Pseudocedrela kotschyi. Phytother Res 2008;22:1013-6.

18. Nene Bi SA, Traore F, Zahoui OS, Soro TY. Composition chimique d'un extrait aqueux de bridelia ferruginea benth. (Euphorbiaceae) et études de ses effets toxicologique et pharmacologique chez les mammifères. Afr Sci 2008; 4:287-305.

19. Kennedy GL Jr., Ferenz RL, Burgess BA. Estimation of acute oral toxicity in rats by determination of the approximate lethal dose rather than the LD50. J Appl Toxicol 1986;6:145-8.

20. Ouedraogo GG, Ouedraogo M, Lamien-Sanou A, Lompo M, Goumbri-Lompo OM, Guissou PI. Acute and subchronic toxicity studies of roots barks extracts of Calotropis procera (Ait.) R. Br used in the treatment of sickle cell disease in Burkina Faso. Br J Pharm Toxicol 2013;4:194-200.

21. Ogbonnia SO, Mbaka GO, Igbokwe NH, Anyika EN, Alli P, Nwakakwa N. Antimicrobial evaluation, acute and subchronic toxicity studies of leone bitters, a Nigerian polyherbal formulation, in rodents. Agric Biol J N Am 2010;1:366-76.

22. Ilboudo S, Ouedraogo M, Some N, Ouedraogo M, Ouedraogo M, Guissou PI. Criblage phytochimique et evaluation de la toxicite aigue de pisolithus tinctorius (basidiomycète). J Sci Pharm Biol 2009;10:6-13

23. Son CG, Han SH, Cho JH, Shin JW, Cho CH, Lee YW, et al. Induction of hemopoiesis by saenghyuldan, a mixture of ginseng radix, paeoniae radix, and hominis placenta extact. Acta Pharm Sinica 2003;24:120-6.

24. Aniagu SO, Nwinyi FC, Akumka DD, Ajoku GA, Dzarma S, Izebe KS, et al. Toxicity studies in rats fed nature cure bitters. Afr J Biotechnol 2005;4:72-8.

25. Patrick-Iwuanyanwu KC, Amadi U, Charles IA, Ayalogu EO. Evaluation of acute and sub-chronic oral toxicity study of baker cleansers bitters - A polyherbal drug on experimental rats. EXCLI J 2012;11:632-40.

26. Adedeji OS, Abubakar MB, Ozegbe PC. Growth-suppressing effect of Calotropis procera (Giant Milkweed)-chronic cynanide toxicity and urinary enzymeexcretion in rabbits. Trop Vet 2002;22:1357.

27. Costa-Silva JH, Lima CR, Silva EJ, Araújo AV, Fraga MC, Ribeiro E Ribeiro A, et al. Acute and subacute toxicity of the Carapa guianensis aublet (Meliaceae) seed oil. J Ethnopharmacol 2008;116:495-500.

28. Dosseh K, Agbonon A, Gbeassor M. Antioxidant and toxicological studies of ethanolic root extract of Byrsocarpus coccineus. J Med Plants Res 2015;9:940-9.

29. Rosidah YM, Sadikun A, Ahmad M, Akowuah GA, Asmawi MZ. Toxicology evaluation of standardized methanol extract of Gynura procumbens. J Ethnopharm 2009;123:244-9.

30. Idoh K, Agbonon A, Potchoo Y, Gbeassor M. Toxicological assessment of the hydroethanolic leaf extract of Clerodendrum capitatum in wistar rats. Pan Afr Med J 2016;24:66.

\footnotetext{
How to cite this article:

Evenamede KS, Kpegba K, Idoh K, Amegnona A, Simalou O, Boyode P,

Oke OE, Gbeassor M. Comparative study of the toxicity of hydroethanolic extracts of the root and stem barks of Cassia sieberiana D.C. on Wistar rats. J App Biol Biotech. 2019;7(03):47-52. DOI: 10.7324/JABB.2019.70309
} 